\title{
FEEDING PREFERENCES OF Microtheca punctigera (Achard) (COLEOPTERA: CHRYSOMELIDAE) FOR SOME BRASSICACEAE PLANTS IN MULTIPLE-CHOICE ASSAYS
}

\author{
Ayres Oliveira Menezes Jr.; Adriana Yatie Mikami; André Keiiti Ide; Maurício Ursi Ventura* \\ UEL/CCA - Depto. Agronomia, C.P. 6001 - 86051-970 - Londrina, PR - Brasil. \\ *Corresponding author $<$ mventura@uel.br $>$
}

\begin{abstract}
Host plant feeding preference is important basic information for the development of insect management strategies. Multiple-choice feeding preference assays were conducted in the laboratory for the chrysomelid beetle, Microtheca punctigera (Achard). Feeding was assessed $72 \mathrm{~h}$ after onset of experiments. With one larva per Petri dish, food items comprised watercress, Nasturtium officinale L., arugula, Eruca sativa L., mustard, Brassica juncea Cosson, Chinese cabbage, B. pekinensis (Lour.) Rupr. and wild radish (Raphanus raphanistrum $\mathrm{L}$.). Feeding ranking preferences were Chinese cabbage, mustard, wild radish, arugula and watercress $\left(7.97,1.85,0.98,0.36\right.$ and $0.11 \mathrm{~mm}^{2}$, respectively). Feeding on Chinese cabbage was 4.31 times more intense than on mustard. The same experiment was repeated with one adult per dish. Responses of males and females were quite similar. Feeding was higher on mustard ( 87.2 and 142.8 for males and females, respectively). Feeding on arugula (51.5 and 132.7) and Chinese cabbage (51.8 and 89.0) were intermediate. Watercress (22.96 and 39.3) and wild radish (12.03 and 28.4) were the least preferred host plants. In a third experiment, ten larvae per dish were used and spinach, Tetragonia expansa Murr., radish, Raphanus sativus L. and collard, B. oleracea var. acephala $\mathrm{L}$., were also included. Daily larval frequencies on each food were also measured. Feeding was similar on Chinese cabbage and mustard (47.89 and 53.78, respectively). Number of insects was greater on mustard, Chinese cabbage and wild radish. Probable explanations for results and proposals for further investigations are discussed.
\end{abstract}

Key words: Brassicaceae, insecta, host plants, consumption

\section{PREFERÊNCIA ALIMENTAR DE Microtheca punctigera (Achard) (COLEOPTERA: CHRYSOMELIDAE) POR ALGUMAS CRUCÍFERAS EM TESTES DE MÚLTIPLA ESCOLHA}

RESUMO: Preferência alimentar é informação básica importante para o desenvolvimento de estratégias de manejo. Experimentos de preferência alimentar com múltipla chance de escolha foram conduzidos em laboratório para o crisomelídeo Microtheca punctigera (Acherd). A alimentação foi avaliada 72h após o início dos experimentos. Com uma larva por placa de Petri, foram utilizadas discos de folhas de almeirão, Nasturtium officinale L., rúcula, Eruca sativa L., mostarda, Brassica juncea Cosson, couve chinesa, $B$. pekinensis (Lour.) Rupr., e nabiça (Raphanus raphanistrum L.). A alimentação em ordem decrescente foi em couve chinesa, mostarda, nabiça, rúcula e almeirão $\left(7,97 ; 1,85 ; 0,98 ; 0,36\right.$ e $0,11 \mathrm{~mm}^{2}$, respectivamente). A alimentação em couve chinesa foi de 4,31 vezes maior do que em mostarda. O mesmo experimento foi repetido com um adulto por placa. Respostas de machos e fêmeas foram similares. A alimentação foi maior em mostarda (87,2 e 142,8 para machos e fêmeas, respectivamente); em rúcula (51,5 e 132,7) e couve chinesa $(51,8$ e 89,0$)$ foi intermediária. Agrião $(22,96$ e 39,3) e nabiça $(12,03$ e 28,4$)$ foram os menos consumidos. Num terceiro experimento, dez larvas por placa foram usadas, incluindo-se também espinafre, Tetragonia expansa Murr., rabanete, Raphanus sativus L., e couve, B. oleracea var. acephala L. A frequiências diárias de larvas em cada alimento foram também medidas. A alimentação foi similar em couve chinesa e mostarda (47,89 e 53,78, respectivamente). O número de insetos foi maior em mostarda, couve chinesa e nabiça. Prováveis explicações da preferência e proposições de novas pesquisas são discutidos.

Palavras-chave: Brassicaceae, insecta, plantas hospedeiras, consumo

\section{INTRODUCTION}

Leaf beetles of the genus Microteca Stal. (Coleoptera: Chrysomelidae) are multivoltine oligophagous insects closely associated with host plants of the family Brassicaceae. In Brazil, they were observed damaging mustard (Brassica juncea Cosson) and watercress (Nasturtium officinale L.) (Racca Filho et al., 1994). In the 
state of Paraná, M. punctigera (Achard) and $M$. semilaevis Stal. occur on some plants of this family, mostly Chinese cabbage [B. pekinensis (Lour.) Rupr.]. In the USA, $M$. ochroloma Stal. occurs on collard ( $B$. oleracea var. acephala L.), mustard (B. juncea Cosson), cabbage (B. oleracea var. capitata), radish (Raphanus sativus L.) and turnip (B. rapa L.) which was determined to be their preferred food in the field (Chamberlin \& Tippins, 1948). Larval and pupal durations were 8.5 and 3.4 days when feeding on watercress (Zorzenon et al., 1996), and 14.7 and 4.4 days on Chinese cabbage (Menezes A. Jr. \& Mazuco, C. unpublished data). There are four larval instars - adults longevity was 44.0 and 67.30 days for males and females on watercress (Zorzenon et al., 1996).

Growers frequently spray chemical insecticides to reduce high populations of crop pest insects in the field. These plants are marketed as "greens" - their leaves are often eaten uncooked in salads, making pesticide residues a concern. In organic farming, attacks of Microtheca beetles can make production impractical and intercropping was not an efficient control strategy (Bowers, 2003).

Basic information for the development of management strategies, including host plant preferences, which could minimize insecticide applications and therefore residues in the greens, is both desirable and necessary. Different feeding responses of $M$. punctigera to host plant species are probable. To confirm this possibility and to establish which species are preferred, and to determine degrees of preference, multi-choice feeding preference experiments were carried out in environmental chambers in the laboratory.

\section{MATERIAL AND METHODS}

Insect rearing and plants - Experiments were conducted in environmental chambers $\left(25.0 \pm 2.0^{\circ} \mathrm{C} ; 70 \pm 10 \% \mathrm{RH}\right)$ in the laboratory. Insects were collected in a Chinese cabbage field in Londrina $\left(23^{\circ} 19^{\prime} \mathrm{S}, 51^{\circ} 12^{\prime} \mathrm{W}\right)$ in the state of Paraná, Brazil and the colony was provided with a mixture of host plants (Chinese cabbage, mustard, wild radish and collard). The mixture of plants was used to avoid preference conditioning due to prior feeding (Lara, 1991).

Preference assays - Leaf discs $(1.7 \mathrm{~cm}$ diameter) were placed in the periphery of Petri dishes ( $9 \mathrm{~cm}$ diameter). Host plants were watercress, arugula (Eruca sativa L.), mustard, Chinese cabbage and wild radish (Raphanus raphanistrum L.). Either one larva or adult was released in the center of the dish [149, 17 and 27 insects (replicates) for larvae, females and males, respectively]. Feeding $\left(\mathrm{mm}^{2}\right)$ was measured $72 \mathrm{~h}$ later. A piece of glass was then placed above the leaf disc and the feeding area recorded on a drawing paper and the number of squares counted.
Another assay, with ten larvae per dish, was carried out with the same host plant species in addition to spinach, Tetragonia expansa Murr., radish and collard (nine insects). Daily larval frequencies on each host species (24, 48 and $72 \mathrm{~h}$ later) and leaf tissue consumed (72 $\mathrm{h}$ later) were measured.

Experimental Design and Statistical Analysis - Assays followed a randomized complete block design. Due to lack of independence of treatments, ranks from one (least preferred) to five or eight (most preferred), depending on the number of treatments, were attributed (Horton, 1995). Percent rank sums in relation to possible maximal score $(100 \%)$ were calculated. Friedman's test $(P<0.05)$ was used to compare results (Conover, 1980).

\section{RESULTS AND DISCUSSION}

With one larva per dish, the order of feeding preferences was Chinese cabbage, mustard, wild radish, arugula and watercress (Table 1). Feeding on Chinese cabbage was 4.31 times greater than on mustard. Feeding on watercress, arugula and wild radish were 1.4, 4.5 and $12.3 \%$, respectively, of the feeding on Chinese cabbage.

In the adult assays, feeding was higher on mustard, for both males and females (Table 1). Feeding on arugula and Chinese cabbage were intermediate. Watercress and wild radish were the least preferred. Although preference ranking was similar between males and females, an apparent tendency for greater feeding by females was observed on all hosts, probably due to nutrient requirements for egg production. In general, females of $M$. ochroloma are significantly heavier and longer than males (Ameen \& Story, 1997a).

With ten larvae per dish, mean numbers of insects were greater on mustard, Chinese cabbage and wild radish, 24, 48 and 72h after onset of the experiment (Table 2). Chinese cabbage and mustard had dissimilar rates of consumption to those observed in the experiment with one larva per dish (Table 1). Quite possibly, larval density affected the responses. Microteca spp. larvae feed in groups (Chamberlin \& Tippins, 1948) and as a result of confining isolated larvae, feeding preference could have been affected. Ventura et al. (2000) found that gregarious behavior affected the responses of Neomegalotomus parvus West. (Hemiptera: Alydidae) to several foods in Petri dish assays.

Although insects were found on wild radish in populations similar to those on mustard and Chinese cabbage, this did not correspond to feeding (Table 2). Feeding on wild radish was $25 \%$ and $28 \%$ of that found on mustard and Chinese cabbage, respectively, although significant differences were not detected. It is probable that the insect was attracted to the plant but the presence of arrestants or lack of feeding stimulants caused relatively weak feeding. 
Table 1 - Preferences of Microteca punctigera in multiple-choice tests (one larva or adult per plate) to host plants expressed as eaten leaf area $\left(\mathrm{mm}^{2}\right) 72 \mathrm{~h}$ after experiment onset, in the laboratory.

\begin{tabular}{lccc}
\hline Food (leaves) & Larvae & Males & Females \\
\hline Watercress & $0.11(0.03)[79.8 \mathrm{~d}]^{*}$ & $22.96(4.75)[54.0 \mathrm{c}]$ & $39.3(9.95)[44.0 \mathrm{c}]$ \\
Arugula & $0.36(0.10)[83.4 \mathrm{~cd}]$ & $51.5(5.50)[76.3 \mathrm{~b}]$ & $132.7(57.16)[75.0 \mathrm{~b}]$ \\
Mustard & $1.85(0.36)[95.4 \mathrm{ab}]$ & $87.2(7.17)[100 \mathrm{a}]$ & $142.8(9.60)[100 \mathrm{a}]$ \\
Chinese cabbage & $7.97(1.63)[100 \mathrm{a}]$ & $51.8(10.06)[72.8 \mathrm{~b}]$ & $89.0(12.60)[77.6 \mathrm{~b}]$ \\
Wild radish & $0.98(0.20)[90.7 \mathrm{bc}]$ & $12.03(5.00)[38.0 \mathrm{~d}]$ & $28.4(8.55)[38.8 \mathrm{c}]$ \\
\hline
\end{tabular}

*Means ( \pm s.e.) [percentage of rank sums in relation to maximum possible score (100\%)]. Percent at each column with a common letter do not differ using Friedman's test [percentage obtained with 149, 17 and 27 replicates (insects) for larvae, males and females, respectively].

Table 2 - Preferences of Microteca punctigera in multiple-choice tests (ten larvae per plate) in response to some host plants expressed as mean numbers of insects on each food (24, 48 and 72 after experiment onset) and feeding $\left(\mathrm{mm}^{2}\right)$, in the laboratory.

\begin{tabular}{|c|c|c|c|c|}
\hline \multirow{2}{*}{ Food leaves } & \multicolumn{3}{|c|}{ Number of insects* } & \multirow{2}{*}{$\frac{\text { Feeding }^{*}}{72 \mathrm{~h}^{* *}}$} \\
\hline & $24 \mathrm{~h}^{* *}$ & $48 \mathrm{~h}^{* *}$ & $72 \mathrm{~h}^{* *}$ & \\
\hline Watercress & $0.78(0.32)[58.9 \mathrm{ab}]$ & $0.55(0.24)[60.33 \mathrm{~b}]$ & $0.44(0.29)[71.3 \mathrm{~b}]$ & $0.33(0.16)[37.4 \mathrm{c}]$ \\
\hline Arugula & $0.33(0.17)[62.4 \mathrm{ab}]$ & $0.11(0.11)[43.80 \mathrm{~b}]$ & $0.22(0.15)[68.3 \mathrm{~b}]$ & $2.56(0.91)[55.6 \mathrm{bc}]$ \\
\hline Mustard & $2.78(0.80)[100 \mathrm{a}]$ & $2.56(0.19)[100 \mathrm{a}]$ & $2.00(0.80)[95.3 \mathrm{a}]$ & $53.78(16.80)[100$ a $]$ \\
\hline Chinese cabbage & $1.22(0.28)[80.3 \mathrm{ab}]$ & $1.55(0.47)[85.1 \mathrm{a}]$ & $1.67(0.70)[94.4 \mathrm{a}]$ & $47.89(15.00)[95.6 \mathrm{a}]$ \\
\hline Wild radish & $2.00(0.52)[88.9 \mathrm{a}]$ & $1.33(0.41)[78.5 \mathrm{a}]$ & $1.11(0.65)[100 \mathrm{a}]$ & $13.40(6.70)[67.0 \mathrm{~b}]$ \\
\hline Spinach & $0.00(0.00)[40.0 \mathrm{~b}]$ & $0.00(0.00)[38 . \mathrm{b}]$ & $0.00(0.00)[53.3 \mathrm{~b}]$ & $00.00(00.00)[28.7 \mathrm{c}]$ \\
\hline Radish & $0.11(0.11)[61.5 \mathrm{ab}]$ & $0.55(0.24)[66.1 \mathrm{ab}]$ & $0.55(0.24)[80.4 \mathrm{a}]$ & $11.11(6.69)[53.9 \mathrm{bc}]$ \\
\hline Collard & $0.44(0.18)[61.5 \mathrm{ab}]$ & $0.55(0.18)[66.1 \mathrm{a}]$ & $0.22(0.22)[69.1 \mathrm{~b}]$ & $5.44(3.11)[63.5 \mathrm{bc}]$ \\
\hline
\end{tabular}

*Means ( \pm s.e.) [percentage of rank sums in relation to maximum possible score $(100 \%)$ ]. Percentage at each column with a common letter do not differ using Friedman's test (5\%) (percent obtained with 9 replicates).

**Time after experiment onset.

Watercress and arugula, which were clearly less preferred by larvae than mustard and Chinese cabbage, were fed upon in relatively greater amounts by adults ( 26 and 59\% of the feeding on mustard, respectively) (Tables 1 and 2). Radish also was less preferred than mustard by M. ochroloma larvae but adult feeding was similar on both host plants (Ameen \& Story, 1997b). Hence preference was affected by life-stage of the beetle.

Chinese cabbage appeared to be the most suitable host plant since feeding on it was high in all assays. Studies on the biology may confirm this hypothesis. Mustard and turnip are the preferred foods by M. ochroloma in multiple-choice assays (Ameen \& Story, 1997b). In biological assessments, the number of eggs per female were similar for mustard, radish and turnip (Ameen \& Story, 1997a).

Glucosinolates, specific allelochemicals from the Brassicaceae family, work in preingestive (as repellents) and postingestive (as toxins) phases of insect host plant selection (Panda \& Klush, 1995). Feeding preference may be strongly affected by allelochemicals and further investigation on their effects on insect feeding may elucidate the reasons for differences in preference (Ventura \& Pinheiro, 1999).
Since $M$. punctigera had a preference for Chinese cabbage (isolated and grouped larvae) and mustard (isolated adults and grouped larvae) the trap cropping strategy could be tested as a more sustainable approach for managing these pests. Chemical insecticides are commonly used to control M. punctigera in conventional cropping systems in spite of not being registered. Insecticide could be tested in small plots of Chinese cabbage or mustard while the other Brassicaceae could be preserved without no spraying. For organics, it would be worthwhile to evaluate whether just the presence of Chinese cabbage and mustard trap cropping would maintain other Brassicaceae free of feeding damage. Alternatively, biological or botanical insecticides could be tested to enhance control in this agroecosystem.

\section{CONCLUSIONS}

Isolated larvae fed mostly on Chinese cabbage in multiple-choice assay. Groups of larvae settled mostly on mustard, Chinese cabbage and wild radish but fed mostly on mustard and Chinese cabbage. Adults (both females 
and males) preferred to feed on mustard and feeding preference was intermediate for arugula and Chinese cabbage.

\section{REFERENCES}

AMEEN, A.O.; STORY, R.N. Fecundity and longevity of the yellowmargined leaf beetle (Coleoptera: Chrysomelidae) on crucifers. Journal of Agricultural Entomology, v.14, p.157-162, 1997a.

AMEEN, A.O.; STORY, R.N. Feeding preferences of larval and adult Microtheca ochroloma (Coleoptera: Chrysomelidae) for crucifer foliage. Journal of Agricultural Entomology, v.14, p.363-368, 1997b.

BOWERS, K. Effects of within-field location of host plants and intercropping on the distribution of Mircotheca ochroloma (Stal) in Mizuna. Gainesville: University of Florida, 2003. 63p. (Thesis-M.S.).

CHAMBERLIN, F.S.; TIPPINS, H.H. Microtheca ochroloma, an introduced pest of crucifers, found in Alabama. Journal of Economic Entomology, v.41, p.979-980, 1948.

CONOVER, W.J. Practical nonparametric statistics. 2.ed. New York: Wiley, 1980. 225p.

HORTON, D.R. Statistical consideration in the designs and analysis of paired-choice assays. Environmental Entomology, v.24, p.179-192, 1995.
LARA, F.M. Princípios de resistência de plantas a insetos. 2.ed. São Paulo: Ícone, 1991.336p.

PANDA, N.; KLUSH, G.V. Host plant resistance to insects. Wallingford: CAB International, 1995. 431p.

RACCA FILHO, F.; RODRIGUES FILHO, I.L.; SANTOS, C.A.C.; RODRIGUES, C.N. Microtheca ochroloma (Coleoptera Chrysomelidae): aspectos taxonômicos e biológicos. Revista Universidade Rural, v.16, p.29-35, 1994.

VENTURA, M.U.; PINHEIRO, J.B. Resistência a insetos. In: DESTRO, D.; MONTALVÁN, R. (Ed.) Melhoramento genético de plantas. Londrina: Editora UEL, 1999. p.465-514.

VENTURA, M.U.; MONTALVÁN, R.; PANIZZI, A.R. Feeding preferences and related types of behaviour of Neomegalotomus parvus. Entomologia Experimentalis et Applicata, v.97, p.309-315, 2000.

ZORZENON, F.J.; IMENES, S.D.L.; BERGAMANN, E.C.; BOOCK, M.V. Biologia de Microtheca punctigera (Coleoptera: Chrysomelidae). Arquivos do Instituto Biológico, v.63, p.7-9, 1996.

Received September 29, 2003

Accepted December 13, 2004 
This article has received corrections in agreement with the ERRATUM published in Volume 62 Number 2. 